\title{
GIANT CONGENITAL MELANOCYTIC NEVUS: LAPORAN KASUS LANGKA
}

\author{
Fitriani, Zahra Ayu, Inda Astri A, Soenarto K \\ Departemen Dermatologi dan Venereologi \\ FK Universitas Sriwijaya/RSU dr. Mohammad Hoesin, Palembang
}

\begin{abstract}
ABSTRAK
Giant congenital melanocytic nevus (GCMN) merupakan penyakit langka yang timbul saat lahir akibat sel melanosit tumbuh berlebih. Lesi pada GCMN sering ditemukan pada area punggung dan paha. Gambaran lesi berupa bercak hiperpigmentasi dengan ukuran lebih dari $20 \mathrm{~cm}$ dan terdapat rambut. Kondisi ini sering dihubungkan dengan neurokutaneus melanositosis dan melanoma maligna. Risiko neurokutaneus melanositosis meningkat signifikans bila lesi giant nevi terdapat pada regio kranial atau garis midline atau disertai lesi satelit. Rerata kumulatif risiko terjadinya melanoma dalam 5 tahun sebesar 4,5\%. Pendekatan terapi masih menjadi tantangan dan bersifat individual bergantung pada usia, lokasi lesi, ukuran, risiko melanoma dan kemungkinan kelainan fungsi akibat tindakan invasif yang dilakukan serta dampak fisiologis terhadap luka pasca tindakan. Dilaporkan bayi perempuan usia 2 hari, lahir pervaginam, cukup bulan dari seorang ibu P4A0 menderita SLE yang diterapi metilprednisolon selama kehamilan. Status generalis dalam batas normal. Status dermatologikus pada regio skalp, fasialis, trunkus, ekstremitas superior dan inferior bilateral tampak makula-plak hiperpigmentasi, multipel, bulat-irregular, lentikuler-plakat, diskret; sebagian terdapat rambut, kulit sekitar normal; terdapat lesi satelit. Pada regio ekstremitas inferior sinistra terdapat lesi giant nevi dengan ukuran lebih dari $20 \mathrm{~cm}$. Pada kasus ini diperlukan observasi yang baik dan pendekatan multidisiplin dalam tatalaksana GCMN.
\end{abstract}

Keyword: Giant congenital melanocytic nevus, gambaran klinis, komplikasi.

\section{GIANT CONGENITAL MELANOCYTIC NEVUS: A RARE CASE REPORT}

\begin{abstract}
Giant congenital melanocytic nevus (GCMN) is a rare disease caused by excessive growth of melanocytes. It appeared since birth. This disease often found on the back and thigh. Lesion of GCNM often appear as a solitary or multiple well defined hyperpigmented hairy plaque measuring $20 \mathrm{~cm}$ or larger. This condition is frequently associated with neurocutaneous melanocytosis and malignant melanoma. The risk of neurocutaneous melanocytosis significantly increases if giant nevus lesion located on cranial or midline region or accompanied by satellite lesions. Cumulative 5-year risk for the growth of melanoma is 4,5\%. Therapeutic approach is still a challenge and varies among each individual according to age, location, size of lesion, risk of melanoma and possibility of function abnormalities from invasive treatment and physiological impact due to post treatment effect. We reported a case of two-days-old full term female, born naturally and full term with GCMN. The mother suffered systemic lupus erythematosus and received methylprednisolone during pregnancy. General appearance was unremarkable. Dermatological physical examination present with a multiple well defined round - irregular hyperpigmented macules and plaques, some area were covered with hair and some surrounded with satellite papules on the truncus, scalp, facialis, extremities superior et inferior bilateral region. There is giant nevi lesion with size $>20 \mathrm{~cm}$ on the left lower extremity. Close observation dan multidiscipline approach is needed for management of GCMN in our case.
\end{abstract}

\section{Korespondensi:}

Keywords: Giant congenital melanocytic nevus, clinical appearance, complication

Jl. Jend. Sudirman KM 3,5

Palembang

Telp\&fax: 0711-314172

Email: fitrianihasan@ymail.com 


\section{PENDAHULUAN}

Congenital melanocytic nevi (CMN) merupakan nevus melanositik yang timbul saat lahir dan suatu penyakit langka dengan insidens 0,005\% atau 1:20.000. Congenital melanocytic nevi merupakan proliferasi jinak sel melanosit di intraepidermal, dermal, atau keduanya. Beberapa CMN dapat berukuran dari beberapa milimeter hingga sentimeter dengan gambaran klinis kadang sulit dibedakan dengan acquired nevi. ${ }^{1,2}$ Gambaran klinis CMN dapat berupa lesi warna coklat tua sampai hitam dengan tepi irregular, permukaan verukosa disertai lesi satelit yang terdapat jauh dari tepi lesi utama. Lesi giant congenital melanocytic nevus (GCMN) disebut juga "bathing trunk", "coat-sleeve" atau "stoking nevi" bergantung pada distribusinya. ${ }^{3}$ Kondisi ini dihubungkan dengan risiko neurokutaneus melanositosis dan melanoma maligna. Risiko neurokutaneus melanositosis meningkat signifikan bila lesi giant nevi terdapat di regio kranial atau garis midline atau disertai lesi satelit. ${ }^{1}$ Risiko terjadinya melanoma maligna 17 kali lipat pada giant nevi dibandingkan dengan populasi umum. Terapi GCMN pada anak merupakan tantangan karena belum terdapat pedoman dan masih menimbulkan masalah yang kontroversi di dermatologi pediatrik. Alasan utama diperlukan terapi karena lesi berisiko menjadi melanoma, mengganggu secara estetik dan menimbulkan efek psikologik berat. ${ }^{4}$

\section{LAPORAN KASUS}

Seorang bayi perempuan, usia 2 hari terdapat tahi lalat di kepala, wajah, badan, lengan dan tungkai sejak lahir. Bayi lahir pervaginam, cukup bulan dan sesuai dengan masa kehamilan. Tampak bercak hitam, sebagian meninggi, bentuk bulat hingga tidak beraturan, seukuran biji jagung hingga lebih besar dari telapak tangan. Pasien merupakan anak ke-4. Ibu pasien sejak 9 tahun sebelumnya didiagnosis sistemik lupus eritematosus (SLE) dan rutin minum obat metilprednisolon. Status generalis bayi dalam batas normal. Status dermatologikus pada regio skalp, fasialis, trunkus, ekstremitas superior dan inferior bilateral tampak makula-plak hiperpigmentasi, multipel, bulatirregular, berukuran lentikuler hingga plakat, diskret; sebagian terdapat rambut, kulit sekitar normal; terdapat lesi satelit. Pada regio ekstremitas inferior sinistra tampak plak hiperpigmentasi dengan ukuran lesi lebih dari $20 \mathrm{~cm}$ (giant lesi). Pasien ini memerlukan observasi untuk mencari kemungkinan adanya gejala melanoma dan neurokutaneus melanositosis.
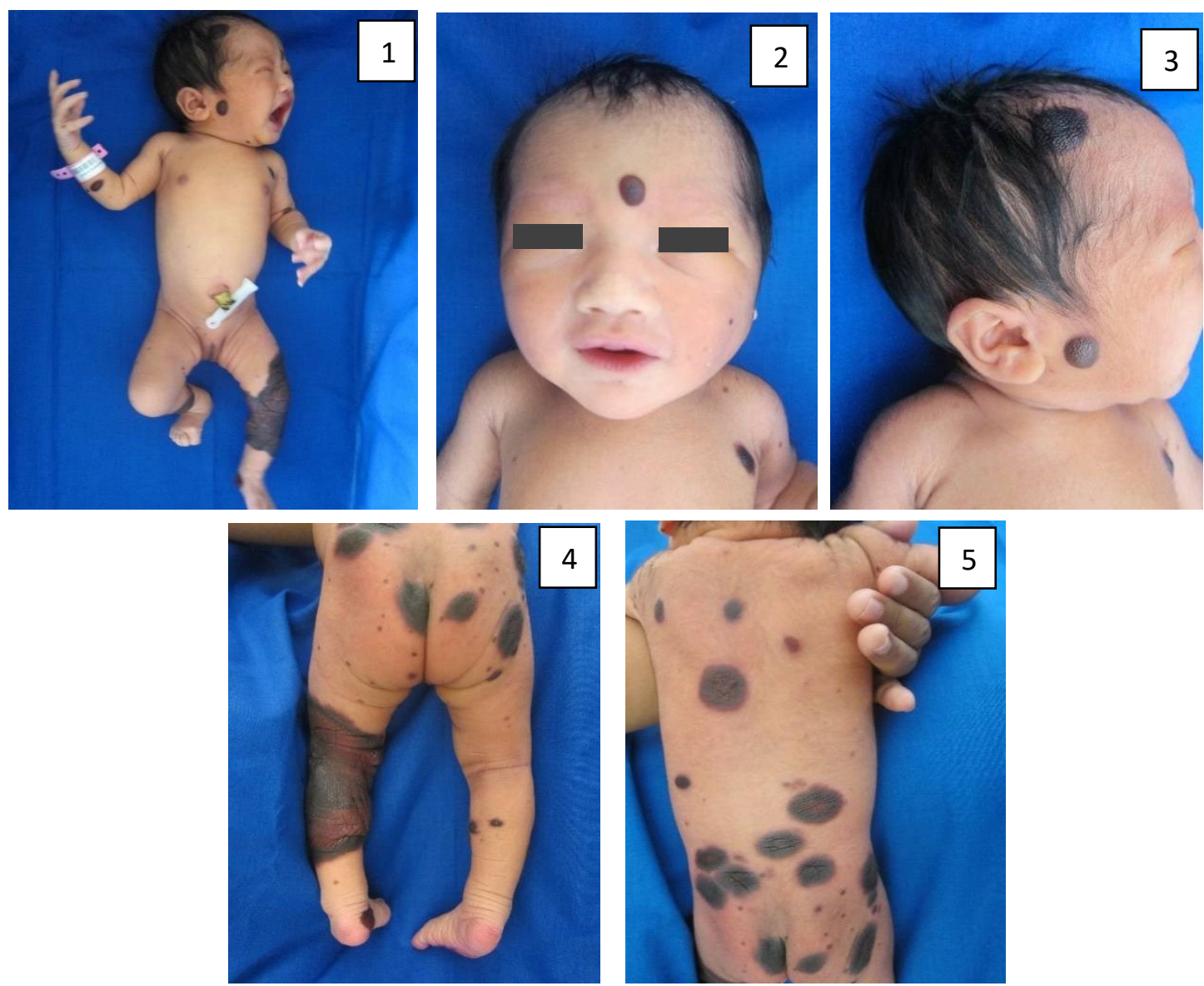

Gambar 1-5. Makula hingga plak hiperpigmentasi pada kepala, badan, lengan dan tungkai. 


\section{DISKUSI}

Congenital melanocytic nevi diklasifikasi menjadi 3 kelompok berdasarkan ukuran yaitu kecil $(<1,5 \mathrm{~cm})$, sedang (1,5 hingga $19,9 \mathrm{~cm})$ dan besar $(>20 \mathrm{~cm})$. Beberapa pengertian giant congenital melanocytic nevi yakni lesi yang sama besar dengan telapak tangan pasien jika lesi ada di kepala dan leher (atau 2 kali lebih besar pada daerah anatomi lain); lebih dari 30\% body surface area (BSA); atau $900 \mathrm{~cm}^{2}$ pada orang dewasa (atau lebih rendah, bila mengikutsertakan area anatomi mayor). ${ }^{1}$ Pada kasus ini, diagnosis GCMN ditegakkan berdasarkan lesi plak hiperpigmentasi berukuran lebih dari $20 \mathrm{~cm}$ di regio ekstremitas inferior sinistra atau lebih dari dua kali lipat ukuran telapak tangan pasien serta makula dan plak hiperpigmentasi menutupi total $>30 \%$ BSA. Lesi GCMN sering ditemukan di badan $(68,4 \%)$, kepala dan leher dengan gambaran klinis awal berupa patch coklat sampai coklat kehitaman, bentuk bulat atau oval, gambaran mottled dan permukaan nodular serta dapat ditemukan lesi satelit. ${ }^{1,5,6}$ Sebuah penelitian melaporkan setidaknya $80 \%$ pasien dengan GCM disertai lesi satelit. ${ }^{2}$ Pada beberapa penelitian, insidens GCMN pada perempuan lebih tinggi dibandingkan dengan laki-laki dengan rasio $3: 2 .^{3}$ Hal ini sesuai dengan kasus ini yakni seorang bayi perempuan.

Congenital melanocytic nevi terbentuk pada usia kehamilan ke-5 hingga 24 minggu. Terdapat dugaan terjadinya kesalahan morfologi neuroektoderma selama proses embriogenesis yang menyebabkan tidak terkendalinya pertumbuhan prekursor melanosit yaitu melanoblast. ${ }^{5}$ Dari segi molekular, perkembangan sel melanosit dikontrol oleh pronto-onkogen c-met dan c-kit. Hepatocyte growth factor (HGF) merupakan sitokin regulator dari sel epitel yang mengekspresikan tyrosine kinase yang dikode oleh c-med. Ekspresi berlebihan faktor ini menyebabkan kelainan diferensiasi, proliferasi dan migrasi sel melanosit. ${ }^{7}$

Pada kasus ini bayi perempuan dengan diagnosis GCMN lahir dari seorang ibu yang menderita SLE dan mendapat terapi metilprednisolon selama kehamilan. Sampai saat ini penulis belum menemukan laporan hubungan antara SLE dan GCMN. Dari literatur diketahui terdapat beberapa obat yang dapat menyebabkan drug-induced eruptif nevi melanositik misalnya obat imunosupresif non-biologik (siklosporin, metotreksat, azatioprin, obat biologik yang menargetkan tumor necrosis factor, imunosupresif biologik (etanercept, alefacept, infliximab, rituximab), kemoterapi dan stimulator melanosit. ${ }^{8}$ Pada kasus ini ibu pasien mendapatkan terapi metilprednisolon selama kehamilan, tetapi belum diketahui apakah pemakaian kortikosteroid dapat menginduksi CMN. Sepanjang pengetahuan penulis, kasus ini merupakan kasus pertama yang melaporkan seorang bayi GCMN, lahir dari ibu dengan SLE dan mendapatkan terapi metilprednisolon.
GCMN sering dihubungkan dengan beberapa kondisi misalnya neurofibromatosis, melanoma dan neurokutaneus melanositosis. ${ }^{1}$ Bhagwat dkk (2009) melaporkan dua kasus GCMN dengan neurofibromatosis dan lipoma. ${ }^{9}$ Insidensi melanoma pada pasien dengan large congenital melanocytic nevi (LCMN) masih kontroversi. ${ }^{5}$ Penelitian yang dilakukan oleh DeDavid dkk. melaporkan dari 289 pasien dengan LCMN, 34 pasien (12\%) berkembang menjadi melanoma kutaneus dan semua pasien dengan melanoma tersebut memiliki CMN di lokasi aksial seperti kepala, leher dan/ atau badan. ${ }^{10}$ Melanoma harus dicurigai ketika terjadi pertumbuhan yang bersifat fokal, terdapat nyeri, perdarahan, ulkus, perubahan pigmen yang signifikan atau gatal.,11 Insiden GCMN yang berhubungan dengan neurokutaneus melanositosis berkisaran antara 2,5 hingga $7 \%$. ${ }^{11}$ Pada penelitian prospektif terhadap 92 pasien dengan large/giant congenital melanocytic nevi, 3 pasien mengalami melanoma di area ekstrakutan yaitu otak, CNS dan retroperineum selama waktu evaluasi 5,4 tahun. ${ }^{2}$ Neurokutaneus melanositosis adalah neuromelanosis yang berhubungan dengan CMN dan dapat melibatkan amigdala, serebrum, serebelum, pons, medula, serta spinal cord. Faktor risiko terbentuknya neurokutaneus melanositosis yakni terdapat GCMN, jenis kelamin laki-laki, beberapa $\mathrm{CMN}$ atau lesi satelit, lesi pada kepala, leher serta midline posterior. Neurokutaneus melanositosis sering asimtomatik atau dapat disertai dengan hidrosefalus, kejang, gangguan fokal neurologis serta retardasi mental. Neurokutaneus melanositosis simtomatik prognosisnya buruk dengan rerata kematian 2-3 tahun setelah terdiagnosis., ${ }^{3,11}$ Pada kasus ini pasien berisiko neurokutaneus melanositosis karena terdapat GCMN di regio ekstremitas inferior sinistra, lesi satelit dan lesi di daerah leher atau midline posterior.

Untuk mengetahui kemungkinan neurokutaneus melanositosis dapat dilakukan pemeriksaan radiologis misalnya magnetic resonance imaging (MRI). Pemeriksaan ini dapat dilakukan pada pasien usia 4-6 bulan karena gambaran deposit melanin dapat kabur bila proses mielinisasi otak normal sudah terjadi. Bila terdapat gangguan neurologis harus dievaluasi oleh dokter bedah saraf. Pemeriksaan MRI dan evaluasi perkembangan neurologi ulang dapat dilakukan secara berkala bila keadaan pasien tetap asimtomatik. Interval skrining MRI lebih baik dikonsultasikan bersama dengan dokter saraf. Pada kasus asimtomatik, kadang dapat ditemukan neurokutaneus melanositosis sebesar $30 \%$ pada pasien. Terdapat beberapa gambaran MRI yang berhubungan dengan neurokutaneus melanositosis yakni beberapa massa postgadoliniumenchancing yang jelas, penebalan difus leptomeninges yang ditandai oleh gadolinium, dan peningkatan sinyal fokal di area setinggi T-1. ${ }^{1,2,11}$ Pada kasus ini, gejala neurologik berupa kejang dan gangguan fokal belum ditemukan, tetapi terdapat faktor risiko untuk neurokutaneus melanositosis sehingga diperlukan observasi dan pemeriksaan lanjutan saat pasien usia 4 bulan. 
Manajemen CMN terutama berhubungan dengan dua faktor yaitu peningkatan risiko menjadi melanoma dan terdapat cacat secara kosmetik. Keputusan untuk menghilangkan CMN bersifat individual dan bergantung pada risiko melanoma, usia, lokasi anatomik, ada tidaknya neurokutaneus melanositosis, tujuan kosmetik dan kesulitan tindakan pembedahan. ${ }^{2}$ Tindakan bedah dianjurkan setelah pasien berusia 6 bulan untuk menurunkan risiko akibat pembedahan dan anestesi. Prosedur pembedahan yang dapat digunakan berupa eksisi serial disertai dengan rekonstruksi misalnya tandur kulit, flap dan free tissue transfer. ${ }^{11}$ Terdapat laporan tindakan eksisi total GCMN yang dilakukan sampai ke kedalaman fasia, namun tidak menghilangkan risiko keganasan secara total karena dapat terjadi melanoma ekstrakutan. ${ }^{6}$ Selain tindakan eksisi total, keberhasilan kuretase pada neonatus oleh Later di Belgia dengan hasil secara kosmetik yang baik dan tidak ditemukan komplikasi selama rawat inap. Keuntungan tindakan kuretase yakni mudah digunakan, tidak membutuhkan alat yang rumit, termasuk prosedur non-traumatik dengan kehilangan darah minimal. Kuretase dapat dilakukan pada usia kurang dari 6 bulan atau sedini mungkin serta dilakukan sampai kedalaman upper dermis. ${ }^{4}$ Pada beberapa minggu pertama kelahiran terdapat celah 'natural' di antara dermis normal dan dermis yang banyak nevomelanosit, memisahkan upper dermis yang mengandung banyak nevus dan lower dermis dengan sedikit nevus. ${ }^{12}$ Teknik kuretase dilakukan mulai dari bagian tengah ke perifer dan jika pada bagian tepi GCMN tidak dapat dilakukan kuretase secara lengkap, maka dilakukan eksisi pada bagian tepi. Kuretase dapat menurunkan risiko melanoma jika dilakukan sedini mungkin dan memberikan hasil kosmetik yang baik. ${ }^{13}$ Zall dkk. melaporkan dari 8 neonatus GCMN yang diterapi kuretase dan diobservasi selama 5,6 tahun, 75\% mengalami pigmentasi kembali namun tidak ada satupun pasien yang mengalami melanoma. $^{12}$

Terdapat juga laporan terkini mengenai penggunaan laser carbondioxide misalnya Er:YAG dan Q-switched laser ruby sebagai resurfacing dan secara selektif mengobati pigmentasi yang dalam, tetapi rekurensi dari pigmentasi masih menjadi masalah karena terdapat sel nevus yang persisten. ${ }^{2,7}$

\section{SIMPULAN}

Congenital melanocytic nevi merupakan penyakit langka dan diduga disebabkan oleh kelainan melanoblast. Congenital melanocytic nevi umumnya asimtomatik, tetapi dapat berubah menjadi ganas bila terdapat lesi berukuran besar (giant), lokasi di regio kranial atau midline atau mempunyai lesi satelit. Terapi GCMN diindikasikan untuk kepentingan kosmetik dan fungsional. Pada kasus GCMN diperlukan observasi berkesinambungan dan pendekatan multidisiplin dalam tata laksananya.

\section{DAFTAR PUSTAKA}

1. Grichnik JM, Rhodes AR, Sober AJ. Benign neoplasias and hiperplasias of melanocyte. Dalam: Wolff K, Goldsmith LA, Katz SI, Gilchrest BA, Paller AS, Lefel DJ, penyunting. Fitzpatrick's Dermatology in General Medicine. Edisi ke-8. New York: McGraw Hill; 2012.h.1377-80.

2. Rabinovitz H, Barnhill RL. Benign melanocytic neoplasia. Dalam: Bolognia JL, Jorizza JL, Rapini RP, Schaffer JV, Callen JP, Cerroni L, penyunting. Dermatology. Edisi ke-3. Edinburgh: Mosby; 2012.h.1871-4.

3. Alikhan A, Ibrahimi OA, Eisen DB. Congenital melanocytic nevi: where are we now?. J Am Acad Dermatol. 2012;67:495.e1-17.

4. De Raeve LE, Roseeuw DI. Curettage of giant congenital melanocytic nevi in neonates. Arch Dermatol. 2002;138:943-7.

5. Viana ACL, Gontijo B, Goulart EMA, Bittencourt FV. A prospective study of patients with large congenital melanocytic nevi and the risk of melanoma. An Bras Dermatol. 2017;92:200-5.

6. Price HN, Schaffer JV. Congenital melanocytic nevi-when to worry and how to treat: Facts and controversies. J Clin Dermatol. 2010;28:293-302.

7. Viana ACL, Gontijo B, Bittencourt FV. Giant congenital melanocytic nevus. An Bras Dermatol. 2013;8:863-78.

8. Perry BM, Nguyen A, Desmond BL, Blattner CM, Thomas RS, Young RJ. Eruptive nevi associated with medication (ENAMs). J Am Acad Dermatol. 2016;75:1045-52.

9. Bhagwat PV, Topkhakhane RS, Shashikumar MBM, Noronha TM, Naidu V. Giant congenital melanocytic nevus (bathing trunk nevus) associated with lipoma and neurofribroma: report of two cases. Indian J Dermatol Venereol Leprol, 2008;75(5):495-8.

10. DeDavid M, Orlow SJ, Provost N, Marghoob AA, Rao BK, Huang CL, et al. A study of large congenital melanocytic nevi and associated malignant melanoma: review of cases in the New York University Registry and the world literature. J Am Acad Dermatol, 1997;36(3):409-16.

11. Arneja JS, Gosain AK. Giant congenital melanocytic nevi of the trunk and an algorithm for treatment. J Craniof Surg. 2005;16:886-93.

12. Tromberg J, Bauer Bm Benvenuto-andrade C, Marghoob AA. Congenital melanocytic nevi needing treatment. Dermatol Ther. 2005;18:135-50.

13. Zaal LH, Mooi WJ, Smitt HJS. Result of early curettage of giant congenital melanocytic nevi; a report of eight cases and review of the literature. Eur J Plast Surg.2008;30:257-62. 